\title{
RUDJER BOŠKOVIĆ INSTITUTE RADIOCARBON MEASUREMENTS XVI
}

\author{
Bogomil Obelić • Ines Krajcar Bronić • Nada Horvatinčić • Jadranka Barešić • Anita Rajtarić \\ Rudjer Bošković Institute, P.O. Box 180, 10002 Zagreb, Croatia. Email: Bogomil.Obelic@irb.hr.
}

ABSTRACT. In this paper, we present dating of archaeological samples performed since our last report (Obelić et al. 2002). Included are results of samples measured by the gas proportional counting (GPC) method until the abandonment of this technique in 2007, as well as results of several series measured by both GPC and liquid scintillation counting (LSC) methods.

\section{INTRODUCTION}

Sample preparation details for the gas proportional counting (GPC) technique are essentially the same as reported earlier (Srdoč et al. 1971, 1979; Obelić 1989), while the details for liquid scintillation counting (LSC) are presented in Horvatinčić et al. (2004). Age calculations follow the conventional protocol (Mook and van der Plicht 1999) based on the Libby half-life of $5570 \pm 30 \mathrm{yr}$ and using AD 1950 as the reference year. Ages and standard deviations (1- $\sigma$ error) of samples are adjusted for stable isotope fractionation to the normalized concentration ratio $\left(\delta^{13} \mathrm{C}=-25 \%\right)$ according to recommendations in Stuiver and Polach (1977) and using the default $\delta^{13} \mathrm{C}$ values. We use oxalic acid I and oxalic acid II as modern standards for GPC and LSC measurements, respectively. In reports, the conventional ${ }^{14} \mathrm{C}$ ages are rounded according to the rules of Radiocarbon. Calibrated ages are calculated from non-rounded ${ }^{14} \mathrm{C}$ conventional ages by using the program OxCal v 3.10 (Bronk Ramsey 2001) with $1-\sigma$ error (68.2\% confidence level). When several calendar age ranges are obtained, the probability for each interval is given. Probabilities less than 5\% are omitted. A new relational database for ${ }^{14} \mathrm{C}$ samples was recently developed (Portner et al. 2009). The quality assurance and quality control system according to ISO 17025 has been improved within the IAEA TC Regional Project on Quality Control and Quality Assurance for Nuclear Analytical Techniques. The laboratory has participated successfully in all ${ }^{14} \mathrm{C}$ intercomparison studies.

\section{CROATIA}

\section{Aljmaš Series}

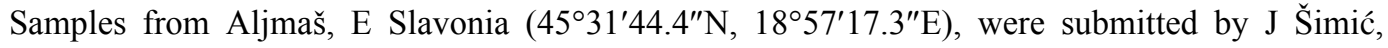
Museum of Slavonia, Osijek, during an investigation of early Eneolithic (Baden culture) in Croatia.

Z-3105 \#1

$4080 \pm 110$

River shells and snails from waste pit (1.14-1.66 m depth) filled with mussels, snails, animal bones, and fragments of pottery. Expected age (J Šimić): 3700-3500 yr (1060-810 cal BC, 68.2\%).

Z-3106 \#2

$4445 \pm 105$

Steer bone found in waste pit, 3.19 m deep. Expected age (J Šimić): 4500-5000 yr (3340-3210 cal BC, 25.5\%; 3190-3150, 6.5\%; 3130-3010, 24.6\%; 2990-2920, 11.7\%).

\section{Crno Vrilo Series}

Bone samples are from the site Crno Vrilo in Dračevac Ninski near Zadar $\left(44^{\circ} 11^{\prime} 53.3^{\prime \prime} \mathrm{N}\right.$, $\left.15^{\circ} 18^{\prime} 45.4^{\prime \prime} \mathrm{E}\right)$, Dalmatia. The site is the first in Dalmatia to reveal remains of Early Neolithic human dwellings (Impresso culture). Samples were collected in 2004 by B Marijanović, Department of Archaeology, University of Zadar (Marijanović 2003). Expected period: 5500 BC.

Z-3398 Block A

$6400 \pm 110$

Depth: 55-70 cm (5480-5280 cal BC, 66.6\%). 
Z-3399 Block C

$7560 \pm 120$

Depth: $15-30 \mathrm{~cm}(6480-6240 \mathrm{cal} \mathrm{BC}, 68.2 \%)$.

\section{Čepin-Ovčara Series}

Charcoal from the Sopot culture site "Turkish graveyard" at Čepin-Ovčara, near Osijek, E Slavonia $\left(45^{\circ} 30^{\prime} 19.8^{\prime \prime} \mathrm{N}, 18^{\circ} 33^{\prime} 57.1^{\prime \prime} \mathrm{E}\right)$, was collected in 2003 by J Šimić, Museum of Slavonia, Osijek. Expected age (J Šimić): 6000-7000 yr.

Z-3263 \#5

$5500 \pm 90$

3.05-3.07 m below housing object with earth floor, SU 16/17 (4460-4240 cal BC, 68.2\%).

Z-3264 \#10

$\mathbf{5 9 0 0} \pm \mathbf{9 0}$

$3.68 \mathrm{~m}$ depth in lower layers of housing pit (half earth-hut), SU 28/29 (4910-4870 cal BC, 6.8\%; $4860-4670,57.9 \%)$.

Z-3439 Dubovo-Košno

$6870 \pm 115$

Charcoal sample 221 (SU 318, square I/48) from the Sopot culture settlement (transition from stage I-B to phase II) Dubovo-Košno near Županja, E Croatia $\left(45^{\circ} 6^{\prime} \mathrm{N}, 18^{\circ} 42^{\prime} \mathrm{E}\right)$, taken during rescue excavations on the highway Zagreb-Belgrade, was collected and submitted in 2004 by B Marijan, Museum Stjepan Gruber, Županja. Previous measurements Z-2969, -2973, -2998, -3045, -3046 are reported in Obelić et al. (2004) (5850-5630 cal BC, 66.5\%).

\section{Dubrovnik Harbor Series}

Wood from pylons from the medieval harbor (Porat) of Dubrovnik (Figure 1), S Dalmatia $\left(42^{\circ} 38^{\prime} 26.4^{\prime \prime} \mathrm{N}, 18^{\circ} 6^{\prime} 40.9^{\prime \prime} \mathrm{E}\right)$, was submitted in 2003 by I Radić Rossi, Croatian Restoration Institute, Zagreb. Expected age: 500 yr (Radić Rossi 2004).

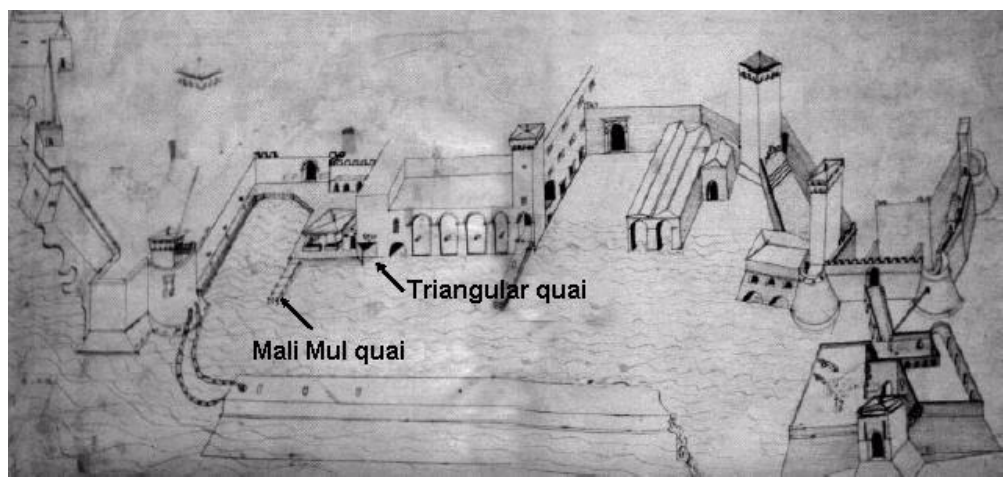

Figure 1 Position of pylons marked on map from the 16th century showing old Dubrovnik harbor (from Ničetić 2003).

Z-3265 Mali Mul, central tree rings

$565 \pm 65$

Wooden pylon from quay Mali Mul ("small quai"), central part (cal AD 1300-1370, 39.0\%; 1380$1430,29.2 \%)$.

Z-3266 Mali Mul, outer tree rings

Wooden pylon from quay Mali Mul, outer part (cal AD 1320-1360, 16.4\%; 1390-1450, 51.8\%).

Z-3289 Triangular quay

$720 \pm 65$

Wooden pylon supporting quai stone construction (cal AD 1220-1310, 57.5\%; 1360-1390, 10.7\%). 


\section{Gudovac-Gradina Series}

Wood and charcoal from the late medieval lowland hill-fort at Gudovac village near Bjelovar, central Croatia $\left(45^{\circ} 52^{\prime} 53.3^{\prime \prime} \mathrm{N}, 16^{\circ} 47^{\prime} 8.3^{\prime \prime} \mathrm{E}\right)$, were collected and submitted in 2004 by T Sekelj-Ivančan (Z-3307) and T Tkalčec (Z-3463 to -3466), Institute of Archaeology, Zagreb (Tkalčec 2005). Comment (T S-I): Around AD 1543, the hill-fort changed its function from being a noblemen's estate into one in a series of fortifications against the Ottomans. The decline of the hill-fort around the mid16 th century is confirmed by the ${ }^{14} \mathrm{C}$ dates.

Z-3307 U-65

$460 \pm 65$

Wooden piece from the moat $(30 \mathrm{~cm}$ long, diameter $7 \mathrm{~cm}$ ), SU-037. Relative depth $1.80 \mathrm{~m}$ (cal AD $1400-1510,63.6 \%)$.

Z-3463 U-257

$315 \pm 80$

Burnt beam from the younger phase of the hill-fort, SU 005, quadrant S50 (cal AD 1480-1650, $68.2 \%)$.

Z-3464 U-290

$420 \pm 80$

Wooden splinters from the older phase, SU 094, quadrant R51 (cal AD 1420-1530, 50.8\%; 1580$1630,17.4 \%)$.

Z-3465 U-359

$420 \pm 65$

Oak spike from construction phase, quadrant T50 (cal AD 1420-1520, 55.3\%; 1590-1630, 12.9\%).

Z-3466 U-370

$190 \pm 75$

Part of the oak pylon, SU 16/17, R50 (cal AD 1640-1700, 16.0\%; 1720-1820, 31.3\%; 1830-1880, $10.2 \% ; 1910-1950,10.7 \%)$.

\section{Hum na Sutli Series}

Samples from the late medieval feudal town of Vrbovec (Figure 2) near Klenovec Humski, Hum na Sutli, Hrvatsko Zagorje, NW Croatia $\left(46^{\circ} 12^{\prime} 33.7^{\prime \prime} \mathrm{N}, 15^{\circ} 43^{\prime} 39.5^{\prime \prime} \mathrm{E}\right)$, according to historical sources known in the period 1267-1497 (Tomičić et al. 2001), were submitted in 2004 by Ž Tomičić, Institute of Archaeology, Zagreb.

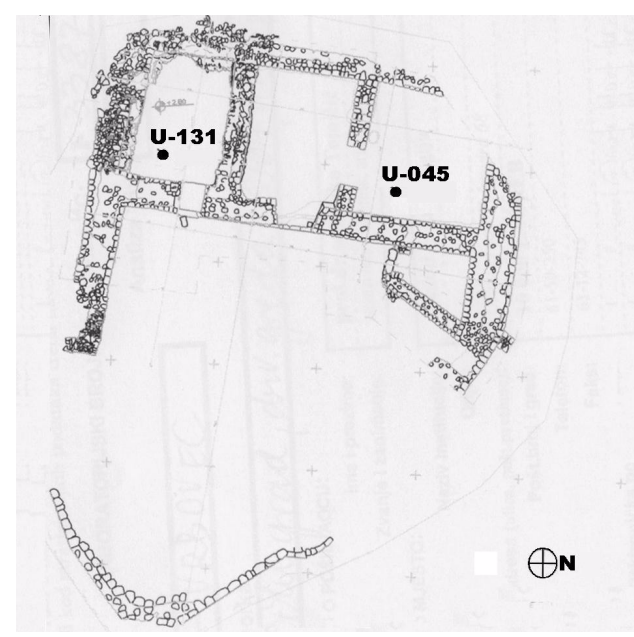

Figure 2 Ground plan of the old town of Vrbovec with the position of samples for ${ }^{14} \mathrm{C}$ analysis. 
Z-3387 PGV-1

$760 \pm 65$

Wooden beam, SU 017, U-045 (cal AD 1210-1300, 68.2\%).

$535 \pm 65$

Z-3388 PGV-2

Wooden beam, SU 038, U-131 (cal AD 1310-1360, 24.2\%; 1380-1450, 44.2\%).

\section{Ilok Series}

Charcoal from Late Bronze Age and medieval layers found in the medieval prince's town of Ilok (Figure 3), E Slavonia $\left(45^{\circ} 13^{\prime} 28.6^{\prime \prime} \mathrm{N}, 19^{\circ} 22^{\prime} 41.4^{\prime \prime} \mathrm{E}\right)$, were submitted in 2004 by Ž Tomičić, Institute of Archaeology, Zagreb. Prehistoric layers belong to the 1st phase Bosut group (transition from the Late Bronze to Early Iron Age) (Ložnjak 2002). In 1267, a town at the same location was first mentioned, having its apogee during the reign of Nicholaus de Illoch (1410-1477), viceroy of Croatia and duke of Transylvania.

Figure 3 Excavation probes in the old town of Ilok with position of samples taken for dating.

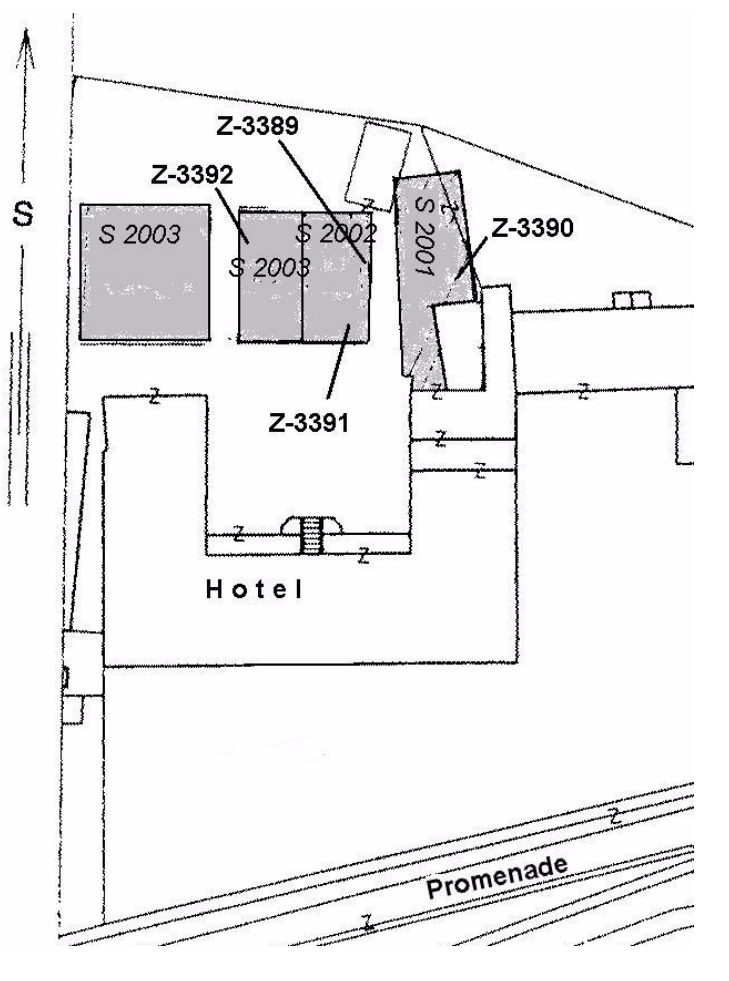

\section{Z-3389 DKI-3}

$760 \pm 100$

Charcoal from burnt layer in Gothic floor, C-3, SU 063, U-390, late medieval (cal AD 1150-1310, $56.9 \% ; 1350-1390,8.6 \%)$.

Z-3390 DKI-1

$3160 \pm 80$

Charcoal from filling of pit, A/B-3, SU 083, U-208, Bosut group (1st phase) of Late Bronze Age (1520-1370 cal BC, $59.5 \% ; 1340-1310,7.3 \%)$.

Z-3391 DKI-2

$2610 \pm 70$

Charcoal from filling of pit, C/D-2, SU 288, U-499. Bosut group (1st phase) of Late Bronze Age (840-750 cal BC, 40.5\%; 690-660, 5.3\%; 640-540, 18.9\%). 
Z-3392 DKI-4

$3485 \pm 60$

Charcoal from oven, F-3, SU 483, U-811, Vatin group of Middle Bronze Age (1890-1730 cal BC, $63.8 \%)$.

\section{Z-3522 Kalnik}

$670 \pm 80$

Wooden board taken from a window hollow in the wall in the medieval town of Kalnik, north of Križevci, central Croatia $\left(46^{\circ} 7^{\prime} 56.2^{\prime \prime} \mathrm{N}, 16^{\circ} 27^{\prime} 46.2^{\prime \prime} \mathrm{E}\right)$. The town was first mentioned in 1243 , having its golden age between 1408 and 1413, when it was the home of Barbara, the second wife of the Roman Emperor and Croato-Hungarian king Sigismund of Luxembourg. Samples were submitted in 2004 by S Bosek, Klanjec (cal AD 1270-1330, 35.5\%; 1340-1400, 32.7\%).

\section{Kamensko Series}

Samples from the Pauline Monastery of Kamensko (Figure 4) near Karlovac $\left(45^{\circ} 28^{\prime} 57.1^{\prime \prime} \mathrm{N}\right.$, $15^{\circ} 35^{\prime} 24.7^{\prime \prime} \mathrm{E}$ ), founded in AD 1404, were submitted in 2005 by A Azinović-Bebek, Croatian Restoration Institute, Zagreb. Expected period (AAB): 13th to 15th century.

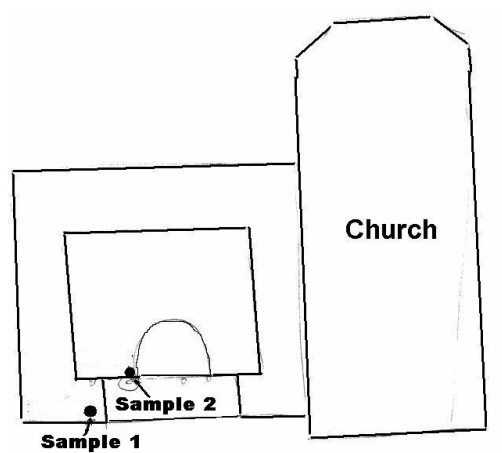

Figure 4 Ground plan of the church and the monastery with the position of samples.

Z-3557 \#1

$490 \pm 75$

Beam from the building, core of post (cal AD 1310-1360, 14.8\%; 1380-1480, 53.4\%).

Z-3558 \#2

$130 \pm 75$

Smaller pieces of wood found in the basement in clay (cal AD 1680-1780, 26.9\%; 1800-1890, $31.0 \% ; 1900-1940,10.4 \%)$.

\section{Kaštel Sućurac-Trstenik Series}

Samples came from the submerged wooden construction of the Roman harbor at Trstenik, Kaštel Sućurac, near Split, Dalmatia $\left(43^{\circ} 32^{\prime} 43.4^{\prime \prime} \mathrm{N}, 16^{\circ} 25^{\prime} 40.2^{\prime \prime} \mathrm{E}\right)$. Samples were found 1.5 to $3 \mathrm{~m}$ below sea level, and were submitted in 2003 by I Radić Rossi, Croatian Restoration Institute, Zagreb (Radić Rossi 2008).

Z-3259 Trstenik 1

$1710 \pm 70$

Wooden remnants of the construction among assembly of amphorae and big Roman urns (cal AD $240-420,68.2 \%)$.

Z-3326 Trstenik 2

$1890 \pm 70$

Wooden pylons bounding the assembly of amphorae (cal AD 50-220, 68.2\%).

Z-3380 Trstenik 3

$2300 \pm 75$

Vine twigs (Vitis vinifera) (410-340 cal BC, 27.3\%; 330-200, 39.9\%). 
Z-3386 Kneževi vinogradi

$6350 \pm 135$

Human bone (femur) found in ground near Kneževi Vinogradi, Baranja, E Croatia $\left(45^{\circ} 45^{\prime} 4.9^{\prime \prime} \mathrm{N}\right.$, $\left.18^{\circ} 43^{\prime} 59^{\prime \prime} \mathrm{E}\right)$, collected in 2004 by J Šimić, Museum of Slavonia, Osijek. Expected age (JŠ): 60008000 yr (5480-5200 cal BC, 62.6\%).

\section{Kruševica-Njivice Series}

Charcoal samples from the Njivice site, Kruševica village near Slavonski Šamac, NE Croatia $\left(45^{\circ} 4^{\prime} 34^{\prime \prime} \mathrm{N}, 18^{\circ} 29^{\prime} 23^{\prime \prime} \mathrm{E}\right)$, containing Neolithic (Sopot culture) and medieval finds, were submitted and collected in 2005 by L Miklik-Lozuk, Museum of Brodsko Posavlje region, during a protective investigation of archaeological layers and pits amid construction of the Zagreb-Belgrade highway.

Z-3525 \#4

$875 \pm 65$

Quadrant C3, SU 022, altitude 84.56-84.32 m (cal AD 1040-1100, 20.8\%; 1120-1230, 47.4\%).

Z-3526 \#39

$3380 \pm 85$

Quadrant F11, SU 004/006, altitude 83.66-83.45 m (1770-1530 cal BC, 68.2\%).

Z-3527 \#86

$2355 \pm 85$

Quadrant I14, SU 034, altitude 85.41-85.02 m (740-680 cal BC, 9.9\%; 550-360, 54.3\%).

Z-3529 \#118

$470 \pm 75$

Quadrant M19, SU 174, altitude 85.35-84.81 m (cal AD 1320-1350, 6.4\%; 1390-1500, 57.6\%).

Z-3530 \#150

$415 \pm 75$

Quadrant I18, SU 060, altitude 85.35-84.81 m (cal AD 1420-1530, 49.0\%; 1570-1630, 19.2\%).

Z-3531 \#182

$\mathbf{3 0 3 0} \pm \mathbf{8 0}$

Quadrant M27, SU 002, altitude 85.38-85.18 m (1410-1190 cal BC, 65.8\%).

Z-3595 \#232

$6115 \pm 60$

Quadrant N24, SU 314, half earth-hut, Sopot culture (measured by LSC) (5210-5160 cal BC, $15.1 \% ; 5080-4940,48.1 \%)$

\section{Lipova Glavica Series}

Wood from the Iron Age (Iapodian culture) site Lipova Glavica near Perušić in the Lika region of central Croatia, was submitted in 2004 by $\mathrm{T}$ Kolak, Museum of Lika region $\left(44^{\circ} 39^{\prime} 9^{\prime \prime} \mathrm{N}\right.$, $\left.15^{\circ} 25^{\prime} 41^{\prime \prime} \mathrm{E}\right)$. Expected period: $700 \mathrm{BC}$.

Z-3505 S1

$2210 \pm 85$

Cover board of the pit, quadrant A-1, SU 16, pit, altitude $667.34 \mathrm{~m}$ (390-170 cal BC, 68.2\%).

Z-3506 S2

$2420 \pm 85$

Supporting beam of the pit, quadrant A-1, SU 22, pit, altitude $665.22 \mathrm{~m}$ (760-680 cal BC, 19.7\%; $670-640,5.4 \% ; 550-400,41.2 \%)$.

Z-3468 Mt. Velebit channel

$200 \pm 80$

Wood from ship construction, bottom of the sea at Mt Velebit channel near Pag Island. Sample submitted in 2004 by I Radić Rossi, Croatian Restoration Institute, Zagreb (cal AD 1640-1700, 17.1\%; $1720-1820,30.1 \%$; 1830-1880, 9.7\%; 1910-1960, 11.4\%). 


\section{Nakovana Series}

Charcoal from Nakovana Cave, west end of the Pelješac Peninsula, S Dalmatia $\left(43^{\circ} 00^{\prime} 8.9^{\prime \prime} \mathrm{N}\right.$, $17^{\circ} 5^{\prime} 1.3^{\prime \prime} \mathrm{E}$ ), contained the undisturbed remains of an ancient Illyrian cult sanctuary dating from the 1st millennium BC (Forenbaher and Kaiser 2001). The earliest evidence of human presence in the cave is from $\sim 6000 \mathrm{yr}$ BC. Samples were submitted in 2004 by S Forenbaher, Institute of Anthropology, Zagreb. Comment (SF): Z-3478 and Z-3480 correspond to the Copper Age phase, which was not yet dated in the Adriatic area, while others correspond to the Bronze Age. Previous results (Obelić et al. 2002): sample Z-3024 (3630 \pm 85 BP), taken from the base of the phallic stalagmite, which was obviously the focus of ritual activity, in order to test the hypothesis that the stalagmite must have been transferred from its original position and placed on a prehistoric layer of Neolithic Age; charcoal sample Z-3025 (1520 \pm 75 BP) taken from carbonate crust precipitated over Hellenistic layer dates precipitation of the crust after abandonment of the sanctuary.

Z-3478 Samples 33 and 35, SU 1013

$4185 \pm 95$

2890-2830 cal BC, 14.6\%; 2820-2660, 46.9\%; 2650-2620, 6.7\%.

Z-3479 Sample 32, SU 1012

$2575 \pm 160$

840-480 cal BC, 60.8\%; 470-410, 6.3\%.

Z-3480 Samples 25 and 26, SU 1010

$4160 \pm 75$

2880-2830 cal BC, 12.7\%; 2820-2660, 49.2\%; 2650-2620, 6.3\%.

Z-3481 Sample 7, SU 1002

$3485 \pm 90$

1920-1680 cal BC, 68.2\%.

Z-3482 Samples 19 and 20, SU 1007

$2750 \pm 100$ $1000-800$ cal BC, $68.2 \%$.

\section{Z-3512 Novalja}

$1935 \pm 135$

Crabs (Galatea strigosa), Novalja, Pag Island, were submitted in 2004 by I Radić Rossi, Croatian Restoration Institute, Zagreb. Age calculated based on 95\% initial activity, typical for seawater (100 cal BC-cal AD 240, 68.2\%).

Z-3312 Osijek

$2065 \pm 70$

Wooden post from Roman bridge over Drava River, Osijek, Slavonia (453' $\left.42.5^{\prime \prime} \mathrm{N}, 18^{\circ} 42^{\prime} 23.9^{\prime \prime} \mathrm{E}\right)$, was submitted in 2003 by M Radić, Museum of Slavonia, Osijek. Expected age (MR): 1850-1900 yr (170 cal BC-cal AD 19, 68.2\%).

\section{Omišalj Series}

Human bones were found near the seaside by the Early Christian basilica of Mira (Figure 5) at the location of the former Roman municipium Flavium Fulfinum on the Pernibe Peninsula, cove Sepen

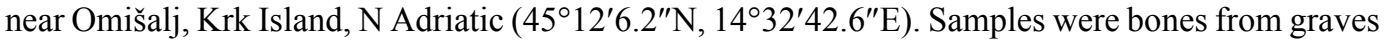
connected with the church (first 5 samples) and femur from the graves G1-G4 (last 4 samples) in the eastern extension of the cloister, submitted in 2002 by M Čaušević-Bully (Z-3078 to -3082) and 2005 by A Matešić (Z-3591 to -3594).

\section{Z-3078 Bisomum south}

$1710 \pm 85$

Femur from skeleton 1, bisomum (double tomb) south, square 3, SU3 (cal AD 230-430, 68.2\%).

Z-3079 Bisomum north, burial C

$1560 \pm 85$

Bones from lower extremities, bisomum north, square 3, SU4 (cal AD 420-600, 68.2\%). 


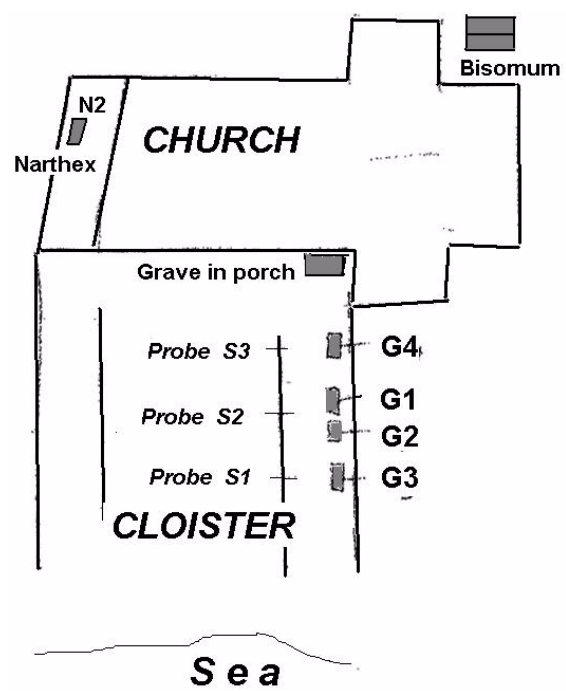

Figure 5 Position of samples for ${ }^{14} \mathrm{C}$ analyses on the Early Christian complex of Mirine.

\section{Z-3080 Bisomum north, burial D}

$1575 \pm 85$

Bones from lower extremities, bisomum, square 3, SU3 (cal AD 400-600, 68.2\%).

Z-3081 Grave in porch

$1320 \pm 85$

Skeleton A in porch, the only sample in situ (others are in ossuary) (cal AD 630-810, 68.2\%).

Z-3082 Grave in narthex

$1500 \pm 85$

Bones from the grave in narthex N2, below the basement, SU2 (cal AD 430-650, 68.2\%).

\section{Z-3591 Grave G1}

$1615 \pm 55$

Femur from grave, probe S2 (cal AD 390-540, 68.2\%).

Z-3592 Grave G2

$1505 \pm 65$

Femur from grave, probe S2 (cal AD 440-490, 13.9\%; 530-640, 54.3\%).

\section{Z-3593 Grave G3}

$1500 \pm 50$

Femur from grave, probe S1 (cal AD 530-640, 68.2\%).

\section{Z-3594 Grave G4}

$1360 \pm 85$

Femur from grave, probe S3 (cal AD 600-770, 68.2\%).

\section{Pakoštane Series}

Parts of a sunken ship found $2.2 \mathrm{~m}$ below sea level near Pakoštane, Dalmatia $\left(43^{\circ} 54^{\prime} 26.1^{\prime \prime} \mathrm{N}\right.$, $\left.15^{\circ} 30^{\prime} 19.7^{\prime \prime} \mathrm{E}\right)$, were submitted in 2004 by Z Brusić, University of Zadar.

Z-3452 Rib of the ship

$1615 \pm 85$ cal AD 340-550, 68.2\%.

Z-3453 Hull of the ship

$1680 \pm 85$ cal AD 240-440, 65.9\%. 
Z-3158 Podvršje-Glavčine

$1485 \pm 90$

Charcoal sample came from Early Christian twin churches at site Glavčine in Podvršje village between Ražanac and Zadar, N Dalmatia $\left(44^{\circ} 15^{\prime} 30.2^{\prime \prime} \mathrm{N}, 15^{\circ} 19^{\prime} 34^{\prime \prime} \mathrm{E}\right)$, in a layer above the basement. Sample submitted in 2002 by T Fabijanić, Faculty of Philosophy, Zadar (Uglešić 2005) (cal AD 430-520, 14.7\%; 530-660, 53.5\%).

\section{Popernjak Series}

Charcoal from the site Popernjak, at the crossing of the Zagreb-Belgrade highway with the road to Bošnjaci, E Slavonia $\left(45^{\circ} 4^{\prime} 11.4^{\prime \prime} \mathrm{N}, 18^{\circ} 47^{\prime} 20.2^{\prime \prime} \mathrm{E}\right)$, was found during prospective studies amid the construction of the highway. Samples submitted in 2004 by B Marijan, Museum Stjepan Gruber, Županja. Urnenfeld Bronze Age culture Barice-Gređani. Expected age: 3300 yr.

Z-3470 SU 53/54, K-36

$2765 \pm 150$

1130-790 cal BC, $65.6 \%$.

Z-3472 SU 5/6, I-15

$2800 \pm 85$

1050-830 cal BC, $68.2 \%$.

Z-3473 SU 21/22, J-13

1050-840 cal BC, $68.2 \%$.

Z-3474 SU 25/26, H-9

1050-830 cal BC, $68.2 \%$.

Z-3475 SU 113/114, J-7

1200-930 cal BC, $68.2 \%$.

$2800 \pm 85$

Z-3476 SU 43/44, T-25

980-820 cal BC, $68.2 \%$.

$2800 \pm 85$

Z-3477 SU 41/42, S/T/U-27

1270-1010 cal BC, $68.2 \%$.

\section{Preko Series}

Wooden samples came from the Franciscan monastery of St Paul on islet Galevac (Školjić), opposite the village Preko on Ugljan Island near Zadar, Dalmatia $\left(44^{\circ} 5^{\prime} 6.2^{\prime \prime} \mathrm{N}, 15^{\circ} 11^{\prime} 18.6^{\prime \prime} \mathrm{E}\right)$. Samples were submitted in 2005 by B Sučić, prior of the Monastery. Comment (BS): Monastery was founded in 1446, dating construction of the church and monastery. Expected period: 12th to 15th century.

\section{Z-3497 Beam \#1}

$\mathbf{5 5 5} \pm \mathbf{7 5}$

Wooden beam from the southern wall of the porch (cal AD 1300-1370, 34.4\%; 1380-1440, 33.8\%).

Z-3626 Beam \#2

$\mathbf{6 3 5} \pm \mathbf{5 0}$

Beam from the tavern, lintel over the window (cal AD 1280-1330, 28.2\%; 1340-1400, 40.0\%).

\section{Z-3627 Beam \#3}

$\mathbf{4 5 5} \pm \mathbf{5 0}$

Rest of bearing beam in the wall (cal AD 1410-1480, 68.2\%).

\section{Slavča Series}

Charcoal samples were unearthed from the prehistoric earth-hut settlement at the hill Slavča near Nova Gradiška, W Slavonia $\left(45^{\circ} 16^{\prime} 14.7^{\prime \prime} \mathrm{N}, 17^{\circ} 22^{\prime} 24.5^{\prime \prime} \mathrm{E}\right)$ and indicated the presence of the 
Eneolithic cultures Sopot, Kostolac, and Vučedol (Skelac 1997). Samples were submitted in 2002 (Z-3234) and 2003 (Z-3290 to -3292) by M Mihaljević, Municipal Museum Nova Gradiška.

Z-3234 SU37

$5610 \pm 100$

Probe 2, quadrant B1,2, altitude 238.22-238.13 m (4550-4340 cal BC, 68.2\%).

Z-3290 SU14

$5980 \pm 90$

Sample 19, probe 1, quadrant BC/3, altitude 238.66-238.44 m (4960-4770 cal BC, 61.2\%; 4760$4720,7.0 \%)$.

Z-3291 SU110

$5990 \pm 90$

Sample 101, probe 1, quadrant C4, altitude $236.64 \mathrm{~m}$ (4990-4770 cal BC, 64.9\%).

Z-3292 SU80

$3995 \pm 65$

Sample 44, Probe 1, quadrant EF/1, altitude 236.83 m (2620-2450 cal BC, 63.1\%).

\section{Z-3385 Svećurje-Radun}

$1920 \pm 125$

Wood 02, VI, sample G-6 from the Old Croatian site Svećurje-Radun near Kaštel Stari $\left(43^{\circ} 34^{\prime} 2.3^{\prime \prime} \mathrm{N}, 16^{\circ} 20^{\prime} 33.5^{\prime \prime} \mathrm{E}\right)$. Submitted 2004 by A Milošević, Museum of Croatian Archaeological Monuments, Split (60 cal BC-cal AD 250, 68.2\%).

\section{Sv Spas Church Series}

Wooden beams came from the transom of a small door on the 2nd floor of a belltower (E side) of the Old Croatian Pre-Romanesque church Sv Spas (St Savior), beside the spring of Cetina River, Dalmatia $\left(43^{\circ} 58^{\prime} 39.8^{\prime \prime} \mathrm{N}, 16^{\circ} 25^{\prime} 47.9^{\prime \prime} \mathrm{E}\right)$, collected in 2000 and submitted in 2003 by A Milošević, Museum of Croatian Archaeological Monuments, Split. Expected building period: 9th century.

Z-3322 Big beam

$1100 \pm 65$ cal AD 880-1020, 68.2\%.

Z-3323 Square beam cal AD 660-880, 68.2\%.

$1265 \pm 95$

Z-3462 Torčec-Blaževo Pole 6

$1860 \pm 85$

Charcoal collected in a supposed hearth of the facility SU 004/005 from medieval settlement at Blaževo Pole 6 near the village of Torčec, close to Koprivnica, NW Croatia $\left(46^{\circ} 13^{\prime} 15.1^{\prime \prime} \mathrm{N}\right.$, $16^{\circ} 53^{\prime} 12.5^{\prime \prime} \mathrm{E}$ ). Submitted in 2004 by T Sekelj-Ivančan, Institute of Archaeology, Zagreb. Result older than expected (Sekelj-Ivančan 2005) (cal AD 50-250, 68.2\%).

\section{Torčec-Gradić Series}

Samples originate from a burnt layer of early medieval earthwork Gradić $N$ of Torčec village near Koprivnica, NW Croatia, submitted in 2002 (Z-3163), 2003 (Z-3308 and -3309), and 2004 (Z-3445) by T Sekelj-Ivančan, Institute of Archaeology, Zagreb (Sekelj-Ivančan and Tkalčec 2004). Results of ${ }^{14} \mathrm{C}$ investigation of Phase III gave a chronological span from the second half of the 12th century to the middle of 13th century. Subsequent dendrochronological analyses of wooden posts (Čufar and Sekelj-Ivančan 2008) showed that the fortification was built immediately after the Tartar incursion into the region ( $\mathrm{AD} 1242$ ), making the year 1263 as the terminus post quem.

Z-3163 Torčec-Gradić 02, \#1

Three identical wood samples came from a burnt layer on the central elevation (U-19, -20, and -21) SU 014, relative depth $1.3 \mathrm{~m}$ (cal AD 1060-1090, 5.3\%; 1150-1280, 58.2\%). 
Z-3308 Torčec-Gradić 03, \#2

$950 \pm 65$

Wooden pointed post U-99 from block 4/5, peak (cal AD 1020-1160, 68.2\%).

Z-3309 Torčec-Gradić 03, \#3

$830 \pm 65$

Charcoal from the base of interior rampart, U-99 from block 4/5, peak (cal AD 1150-1280, 68.2\%).

Z-3445 Torčec-Gradić 03, \#4

$565 \pm 65$

Trunk from the support of a bridge across the Gliboki Potok stream, U-107 (cal AD 1300-1370, $39.1 \% ; 1380-1430,29.1 \%)$

\section{Torčec-Ledine Series}

Charcoal from the early medieval site Ledine at Torčec village near Koprivnica was submitted in 2002 by T Sekelj-Ivančan, Institute of Archaeology, Zagreb. Comment (TSI): According to the ${ }^{14} \mathrm{C}$ dates, the site existed in 10th and 11th century and was abandoned due to a flood of the Gliboki Potok stream (Sekelj-Ivančan 2004).

Z-3164 U-2 and U-6, SU 008/009

$980 \pm 80$

cal AD 990-1160, 68.2\%.

Z-3167 U-60 and U-94, SU 015/016

$1115 \pm 90$

cal AD 810-1020, 65.7\%.

Z-3310 U117 and U128, SU 021, Square H77

$1150 \pm 65$

Charcoal from filling of medieval house (cal AD 810-980, 64.3\%).

Z-3311 U-133 and U136, SU 021

$985 \pm 65$

Charcoal from filling of medieval house (cal AD 990-1070, 36.6\%; 1080-1160, 31.6\%).

Trogir-Pantana Series

A wooden construction was found in mud on sea bottom, $2 \mathrm{~m}$ below sea level in Pantana Swamp natural reserve near the historic town of Trogir, Dalmatia $\left(43^{\circ} 31^{\prime} 31.6^{\prime \prime} \mathrm{N}, 16^{\circ} 16^{\prime} 29^{\prime \prime} \mathrm{E}\right)$. Samples were submitted in 2003 by I Radić Rossi, Croatian Restoration Institute, Zagreb (Radić Rossi 2008).

Z-3305 Pylon \#1

$1250 \pm 65$ cal AD 680-830, 59.2\%; 840-870, 9.2\%.

Z-3306 Beam \#2

120 cal BC-cal AD 30, 64.8\%.

$2035 \pm 60$

\section{Turska Peć Series}

Charcoal from Turska Peć Cave near Dugi Rat, Dalmatia (43⒉ $\left.27^{\prime} 4^{\prime \prime} \mathrm{N}, 16^{\circ} 37^{\prime} 54^{\prime \prime} \mathrm{E}\right)$, was submitted in 2004 by D Kliškić, Archaeological Museum, Split. Comment (DK): Finds from Late Neolithic Hvar-Lisičići culture; expected period: 3000 BC.

Z-3396

$1480 \pm 110$

Quadrant H22, gray sediment, zone 6 (cal AD 430-660, 69.2\%).

Z-3397

$1235 \pm 70$

Quadrant G24, and H24, brown humid layer 2 (cal AD 690-890, 68.2\%). 


\section{Varaždin Series}

Prospective excavations at several sites near Varaždin, during construction of the Zagreb-Budapest highway, led to samples submitted in 2003 by L Bekić, Ministry of Culture, Republic of Croatia.

Z-3275 Ciglenica, Probe X, layer 3

$515 \pm 65$

Wooden sample, basement of burnt house from the early medieval site of Ciglenica, Varaždinske Toplice spa $\left(46^{\circ} 12^{\prime} 55^{\prime \prime} \mathrm{N}, 16^{\circ} 24^{\prime} 43^{\prime \prime} \mathrm{E}\right)$. Expected period (LB): 11th century (cal AD 1320-1350, $16.1 \% ; 1390-1450,52.1 \%)$.

\section{Z-3276 Ciglenica, Probe B, layer 6}

$920 \pm 65$

Charcoal, beams from filled waterbed from site Ciglenica. Expected period (LB): 12th century (cal AD 1030-1190, 68.2\%).

\section{Z-3281 Bukovje-Banjšćina}

$2065 \pm 70$

Pit 1 from probably Hallstatt site $\left(46^{\circ} 14^{\prime} 56^{\prime \prime} \mathrm{N}, 16^{\circ} 24^{\prime} 22^{\prime \prime} \mathrm{E}\right)$. Expected period (LB): $650 \mathrm{BC}$ (180 cal BC-cal AD 20, 68.2\%).

Z-3282 Jakopovec-Husta

$1970 \pm 70$

Waste pit 1 , probably La Téne site $\left(46^{\circ} 14^{\prime} 95^{\prime \prime} \mathrm{N}, 16^{\circ} 24^{\prime} 00^{\prime \prime} \mathrm{E}\right)$. Expected period (LB): $300 \mathrm{BC}$ (50$130 \mathrm{cal} \mathrm{BC}, 68.2 \%)$.

Z-3314 Jakopovec-Blizna A6

$2695 \pm 70$ Charcoal, $2 \mathrm{~m}$ deep in sandy layer, from the Jakopovec-Blizna site near Varaždin $\left(46^{\circ} 14^{\prime} 42.4^{\prime \prime} \mathrm{N}\right.$, $\left.16^{\circ} 24^{\prime} 47.1\right)$. Pit and earth-hut from Lasinja culture (Eneolithic), probe A, pit 6, layer 6 (910-790 cal BC, $68.2 \%)$.

\section{Z-3316 Jakopovec-Blizna A11}

Charcoal, $1.5 \mathrm{~m}$ deep in sandy layer, from Celtic half-earth-hut, La Téne culture, probe A, pit 11, layer 4. Expected period (LB): 250 to $50 \mathrm{BC}$ (170 cal BC-cal AD 30, 68.2\%).

\section{Vinkovci-Sopot Series}

Charcoal samples from tell Sopot near Vinkovci $\left(45^{\circ} 15^{\prime} 49.2^{\prime \prime} \mathrm{N}, 18^{\circ} 45^{\prime} 55.4^{\prime \prime} \mathrm{E}\right)$ were collected and submitted in 2001 by M Krznarić-Škrivanko, Town Museum Vinkovci. Samples belong to the late Neolithic Sopot culture, specifically to the Lengyel interaction sphere (Protolengyel) (Baldia 2009). Other measurements of samples from this site (Z-2752, -2753, -2754, -2827, -2909, -2911) were published in Obelić et al. $(2002,2004)$.

Z-3139

$6020 \pm 100$

Charcoal from house SU 23, probe 3, square A-8, depth 3.54-3.67 m. Stage II-A of the Sopot culture (5050-4780 cal BC, 68.2\%).

Z-3140

$6010 \pm 100$

Charcoal from house SU 23, probe 3, square C-6, depth $3.61 \mathrm{~m}$. Stage II-A of the Sopot culture (5040-4770 cal BC, 66.5\%).

Z-3141

$5960 \pm 100$

Charcoal from house SU 6, of the house SU 23, probe 3, square D-11, depth $2.74 \mathrm{~m}$. Stage II-A of the Sopot culture (4960-4710 cal BC, 68.2\%).

Z-3143

$5840 \pm 100$

Charcoal from house SU 53, probe 3, square G/H-7, depth 3.58-3.99 m. Stage II-B of the Sopot culture (4800-4580 cal BC, $64.2 \%)$. 


\section{SLOVENIA}

\section{Z-3507 Ajdovska Jama}

$1810 \pm 80$

Charcoal from a fireplace at the entrance to Ajdovska Jama Cave, the site of a systematic excavation of Neolithic settlement, location Silovec at Nemška Vas near Krško, Slovenia (45 57'19.2"N, $15^{\circ} 25^{\prime} 31.6^{\prime \prime} \mathrm{E}$ ), was submitted in 2004 by A Jovanović, Regional Museum Brežice, Slovenia. Earlier measurements: Z-1042 to -1045 (Srdoč et al. 1984); Z-1178, -1179, -1554, -1602, -1603 (Srdoč et al. 1987); Z-1822, -1860 (Srdoč et al. 1989); Z-2042 to -2044, -2123, -2179 (Srdoč et al. 1992); Z2300 and -2301 (Obelić et al. 1994) (cal AD 120-330, 65.7\%).

Z-3467 Bay of Koper

$1910 \pm 80$

Wood from sunken ship, bay of Koper, Slovenia $\left(45^{\circ} 32^{\prime} 49.2^{\prime \prime} \mathrm{N} 13^{\circ} 43^{\prime} 25.7^{\prime \prime} \mathrm{E}\right)$, submitted in 2004 by

F Bonin, Maritime Museum in Koper, Slovenia (cal AD 1-220, 68.2\%).

\section{Čateški Grič Series}

Charcoal from the site Čateški Grič near Brežice, E Slovenia $\left(45^{\circ} 53^{\prime} 36^{\prime \prime} \mathrm{N}, 15^{\circ} 36^{\prime} 00^{\prime \prime} \mathrm{E}\right)$, was recovered during archaeological investigations at the Ljubljana-Zagreb highway. The site represents the Copper, Bronze, and Iron cultures, as well as the Roman period and Middle Ages. Samples submitted in 2004 by S Olić, Institute for Protection of Cultural Monuments, Unit Novo Mesto.

Z-3394 \#1, SU-103

$320 \pm 60$

cal AD 1490-1650, 68.2\%.

Z-3395 \#2

$460 \pm 60$

cal AD 1400-1490, 68.2\%.

Z-3447 Gorenje Skopice

$2800 \pm 85$

Charcoal, SU 014, quadrant B5, from cave near Gornje Skopice, Brežice, E Slovenia (45 54'21.6"N,

$\left.15^{\circ} 32^{\prime} 50.12^{\prime \prime} \mathrm{E}\right)$. Submitted in 2004 by U Bavec, Institute for Protection of Cultural Monuments, Unit Novo Mesto B5 (1050-830 cal BC, 68.2\%).

\section{Gorenji Mokronog Series}

Charcoal from late Roman and early medieval site Gorenji Mokronog near Trebnje, E Slovenia $\left(45^{\circ} 55^{\prime} 15^{\prime \prime} \mathrm{N}, 15^{\circ} 9^{\prime} 25^{\prime \prime} \mathrm{E}\right)$, was submitted in 2004 by S Olić.

Z-3448 Probe 4, SU 052, quadrant $21 \quad 1755 \pm 80$ cal AD 210-390, 61.0\%.

$\begin{array}{ll}\text { Z-3449 Probe 4, SU 052, quadrant 22-23 } & 1610 \pm 65\end{array}$

Filling of pit 051 (cal AD 380-540, 68.2\%).

Z-3450 Probe 4, SU 072, quadrant 36

$1450 \pm 80$

cal AD 530-670, 68.2\%.

\section{Krog-Pod Kotom Series}

Charcoal samples from the Eneolithic Retz-Gajary culture site of Pod Kotom, Jug pri Krogu near Murska Sobota $\left(46^{\circ} 37^{\prime} 30.2^{\prime \prime} \mathrm{N}, 16^{\circ} 08^{\prime} 13.0^{\prime \prime} \mathrm{E}\right)$, were found during prospective excavations on the Maribor-Budapest highway, section Vučja Vas-Beltinci MP03/2, collected in 2002 by I Šavel, Regional Museum Murska Sobota. Expected period: 3500-2100 BC. Comment (Sankovič 2009): The phases belong to the transition of Bronze Age A1 to A2 (Markovic 2003). ${ }^{14} \mathrm{C}$ dates of layers SU 010C (Z-3173), SU 311 (Z-3175), and SU 340 (Z-3176) give the period between 1900 and 1500 
BC (Obelić 2009); therefore, the duration of the Early Bronze Age at the site should be continued also in the beginning of level B1 Bd.

Z-3170 Sector V, quadrant 52, SU 120, PPN 86, \#1 and

$18,300 \pm 400$

Sector IV, quadrant 12, SU 36, PPN 3, \#2

20,400-19,100 cal BC, 68.2\%.

Z-3173 Sector I, quadrant 78, SU 010c, \#4

$3300 \pm 110$

1750-1490 cal BC, 66.0\%.

Z-3174 Sector III, quadrant 40, SU 10b, \#5

$4290 \pm 140$

$3100-2830$ cal BC, 43.5\%; 2820-2660, 22.9\%.

Z-3175 Sector II, quadrant 20, SU 311, \#6

$3455 \pm 105$

1890-1620 cal BC, $67.2 \%$.

Z-3176 Sector II, quadrant 21, SU 340, \#7

$3280 \pm 85$

1690-1490 cal BC, 59.9\%; 1480-1450, 8.2\%.

\section{Krog-Za Raščico Series}

Charcoal samples from site Za Raščico, Krog near Murska Sobota $\left(46^{\circ} 39^{\prime} 0^{\prime \prime} \mathrm{N}, 16^{\circ} 9^{\prime} 17^{\prime \prime} \mathrm{E}\right)$ on highway route section Vučja Vas-Beltinci were collected and submitted in 2002 by I Šavel, Regional Museum Murska Sobota. Comment (IŠ): Samples supposed to belong to the Early Bronze Age culture Vinkovci-Somogyvár ( 2300 BC) and Iron Age culture Hallstatt (700-600 BC).

Z-3177 Sector II, quadrant 35, SU 360, \#1

$3775 \pm 90$

Vinkovci-Somogyvár (2340-2110 cal BC, 54.0\%; 2100-2030, 13.2\%).

Z-3178 Sector I, quadrant 1, SU 539, \#2

$3710 \pm 75$

Vinkovci-Somogyvár (2210-2010 cal BC, 62.3\%; 2000-1970, 5.9\%).

Z-3179 Sector V, quadrant 75, SU 412, \#3

$3655 \pm 75$

Vinkovci-Somogyvár (2140-1920 cal BC, 68.2\%).

Z-3180 Sector VII, quadrant 227, SU 66, \#4

$1815 \pm 85$

Hallstatt (cal AD 120-340, 64.1\%).

Z-3181 Sector VII, quadrant 229, SU 632, \#5

$1915 \pm 85$

Hallstatt (cal AD 1-200, 68.1\%).

Z-3182 Sector Ia, quadrant 8a, SU 670, \#6

$1750 \pm 135$

Vinkovci-Somogyvár (cal AD 120-430, 68.2\%).

Z-3183 Sector Ia, quadrant 7a, SU 672, \#7

$2515 \pm 85$

Vinkovci-Somogyvár (800-520 cal BC, 68.2\%).

Z-3184 Sector II, quadrant 121, SU 597, \#8

$3520 \pm 90$

Vinkovci-Somogyvár (1960-1730 cal BC, 65.6\%).

Z-3185 Sector I, Ia, quadrants 1a, 1b, 1c, SU 539, \#9 $\quad 1400 \pm 130$

Vinkovci-Somogyvár (cal AD 530-780, 65.5\%).

\section{Loke Series}

Charcoal samples were taken during protective archaeological excavations at the Ljubljana-Zagreb

highway, at the Early Bronze Age site of Loke, Bela Cerkev near Novo Mesto in Slovenia 
$\left(45^{\circ} 52^{\prime} 01^{\prime \prime} \mathrm{N}, 15^{\circ} 16^{\prime} 31.3^{\prime \prime} \mathrm{E}\right)$, submitted in 2003 by U Bavec, Institute for Protection of Cultural Heritage, unit Novo Mesto, Slovenia. Comment (UB): Ceramics are Litzen-type.

Z-3327 SU 026, quadrant 19, \#1 $2580-2330$ cal BC, $66.2 \%$.

$3965 \pm 85$

Z-3328 SU 021, quadrant 20, \#2

$3295 \pm 75$

$1690-1500$ cal BC, $68.2 \%$.

Z-3329 SU 017, quadrant 19, \#3

$3260 \pm 100$

1640-1430 cal BC, $64.1 \%$.

Z-3330 SU 052, quadrant 20, \#4

$4575 \pm 115$

$3510-3420$ cal BC, $14.0 \%$; 3390-3090, 54.2\%.

Z-3331 SU 020, quadrant 21, \#5

$4970 \pm 85$

3920-3870 cal BC, 10.8\%; 3810-3650, 57.4\%.

Z-3336 SU 008, quadrant 20/2, \#10

$3490 \pm 95$

1940-1680 cal BC, $68.2 \%$.

Z-3337 SU 008, quadrant 9/11, \#11

$3180 \pm 120$

1620-1310 cal BC, 67.3\%.

Z-3339 SU 008, quadrant 9/9, \#13

$3545 \pm 135$

2040-1730 cal BC, $61.2 \%$.

Z-3343 SU 045, quadrant 19, \#17

$3300 \pm 115$

1690-1440 cal BC, $65.4 \%$.

Z-3347 SU 052, quadrant 20, \#21

2350-2030 cal BC, 65.0\%.

$3780 \pm 110$

Z-3350 SU 020, quadrant 21, \#24

$5060 \pm 85$

3690-3770 cal BC, $68.2 \%$.

Z-3355 SU 052, quadrant 20, \#29

$3875 \pm 90$

2470-2270 cal BC, 55.4\%; 2260-2200, 12.8\%.

$3645 \pm 155$

Z-3358 SU 061, quadrant 20, \#32

2210-1860 cal BC, 57.9\%; 1850-1770, 8.1\%.

Z-3359 SU 028, quadrant 19, \#33

$3755 \pm 65$

2290-2110 cal BC, 50.3\%; 2100-2030, 17.9\%.

Z-3363 SU 070, quadrant 19, \#37

1880-1840 cal BC, 7.0\%; 1830-1520, 61.2\%.

$3390 \pm 135$

\section{Pragersko Series}

Charcoal from excavations at the Stražgonjca-Lavše site at the bypass road of Pragersko near Ptuj $\left(46^{\circ} 24^{\prime} 22.3^{\prime \prime} \mathrm{N}, 15^{\circ} 41^{\prime} 26.8^{\prime \prime} \mathrm{E}\right)$, NE Slovenia, were collected in 2002 by M Lubšina-Tušek.

Z-3228 SU 920

$3480 \pm 90$

cal AD 340-600, 66.2\%. 
Z-3229 SU 3, pit

$4275 \pm 80$

cal AD 540-780, 68.2\%.

$3910 \pm 85$

Z-3230 SU 11, pit

cal AD 330-540, 63.5\%.

\section{Ptuj Series}

Charcoal from excavations at Volkmerjeva, Viktorina Ptujskega, and Koresova streets, Ptuj, NE Slovenia $\left(46^{\circ} 25^{\prime} 11.9^{\prime \prime} \mathrm{N}, 15^{\circ} 52^{\prime} 11.1^{\prime \prime} \mathrm{E}\right)$, were collected in 2002 by M Lubšina-Tušek. Previous measurements of samples (Z-2988, -2989, -3013, -3015, -3019, -3020, -3021, -3022) from various locations in Ptuj (Viktorina Ptujskega str., Mali Grad, Parking place, Volkmerjeva and Koresova streets) reveal Eneolithic to Roman periods (Obelić et al. 2002).

Z-3112 \#1

$2760 \pm 85$

Volkmerjeva cesta, SU II, quadrant 9, grave 5 (1000-820 cal BC, 68.2\%).

Z-3113 \#2

$1900 \pm 80$

Volkmerjeva cesta, quadrant 9, "lisa” XXV (cal AD 20-230, 68.2\%).

Z-3114 \#3

$5625 \pm 80$

Volkmerjeva cesta, quadrant 29, Neolithic object 2 (4540-4350 cal BC, 68.2\%).

Z-3115 \#4

$2930 \pm 70$

Volkmerjeva cesta, SU 3, quadrant 12 (1260-1230 cal BC, 6.0\%; 1220-1010, 62.2\%).

Z-3116 \#5

$1840 \pm 85$

Volkmerjeva cesta, pit P 1099 (cal AD 70-260, 63.7\%).

Z-3117 \#6

$2795 \pm 85$

Viktorina Ptujskega str., grave 1, upper Hallstatt (1020-830 cal BC, 67.0\%).

Z-3118 \#7

$2065 \pm 85$

Koresova str, pit III (fountain) 1119/51, Hajdna (180 cal BC-cal AD 30, 66.6\%).

\section{Ribnica Series}

Archaeological investigations in the former Roman station Romula (dated by coins) along the Ljubljana-Zagreb highway at Ribnica near Brežice, E Slovenia $\left(45^{\circ} 51^{\prime} 57.1^{\prime \prime} \mathrm{N} 15^{\circ} 40^{\prime} \mathrm{E}\right)$, were collected in 2001-2003 by S Olić, Institute for Protection of Cultural Monuments, Unit Novo Mesto.

Z-3146 \#43, \#44, \#45

$1430 \pm 115$

Charcoal, remnants of prehistoric object, SU 413, probe 7, $\mathrm{d}=180 \mathrm{~cm}$ (cal AD 430-520, 9.5\%; 530$720,56.1 \%)$

Z-3147 \#65

$2525 \pm 90$

Charcoal, remnants of prehistoric object, SU 413, probe 7, $d=190 \mathrm{~cm}(800-520 \mathrm{cal}$ BC, $68.2 \%)$.

Z-3162 \#221

$3355 \pm 95$

Wooden remnants in prehistoric pit, depth $2.5 \mathrm{~m}$, SU 1081, sector VIII (1750-1520 cal BC, 68.2\%).

Z-3189 \#222

$1605 \pm 115$

Charcoal in grave, Roman period, depth 1.5 m, SU 1501, sector VII, Probe III, quadrant A-11 (cal AD 340-600, 66.2\%). 
Z-3190 \#226

$1380 \pm 115$

Charcoal from grave, Roman period, SU 1519, sector VII, quadrant A-4 (cal AD 540-780, 68.2\%).

\section{Z-3191 \#229}

$1645 \pm 80$

Charcoal from the beam along the Roman wall, SU 818, sector VII, quadrant A-7 (cal AD 330-540, $63.5 \%)$.

Z-3192 \#230

$1760 \pm 80$

Charcoal in grave, Roman period, SU 2526, sector VII, quadrant A-5/6 (cal AD 210-390, 59.2\%).

Z-3193 \#273

$1595 \pm 80$

Charcoal in grave, Roman period, SU 1544, sector VII, quadrant A-19 (cal AD 380-570, 68.2\%).

Z-3194 \#274

$1595 \pm 80$

Charcoal in grave, SU 1533, sector VII, quadrant A-21 (cal AD 380-570, 48.2\%).

Z-3195 \#327

$1775 \pm 85$

Charcoal, SU 1866, Roman period, sector VIII, quadrant J-22 (cal AD 130-350, 66.1\%).

Z-3196 \#121

$1500 \pm 100$

Charcoal, Roman period, SU 621, sector IV, Probe B (cal AD 430-650, 68.2\%).

Z-3198 \#154

$2000 \pm 95$

Charcoal, Roman period, SU 694, sector IV, quadrant A-27 (120 cal BC-cal AD 90, 62.0\%; cal AD $100-130,5.4 \%)$.

Z-3199 \#329

$1680 \pm 80$

Charcoal from ruins layer, Roman period, SU 1451, sector IV, quadrant D-26 (cal AD 240-440, $68.2 \%)$.

Z-3202 \#110

$205 \pm 80$

Charcoal, SU 722, Antique period, sector VI, Probe 2 (cal AD 1630-1700, 18.2\%; 1720-1820, $29.9 \%$; 1830-1880, 10.0\%; 1910-1950, 10.1\%).

\section{Z-3203 \#136}

$1505 \pm 80$

Charcoal from waste pit, Roman period, SU 724, sector VIII, Probe 2 (cal AD 460-500, 9.4\%; 530$640,52.5 \%)$.

Z-3205 \#162

$1660 \pm 80$

Charcoal from waste pit, Roman period, SU 740, sector VI, Probe 4/3 (cal AD 250-310, 11.1\%; $320-470,48.6 \%$; 480-540, 8.4\%).

Z-3206 \#180

$1600 \pm 65$

Charcoal from grave, Roman period, SU 745, sector VI, Probe 4/2/3 (cal AD 390-540, 68.2\%).

Z-3207 \#203

Charcoal from pit, Roman period, SU 753, sector VI, Probe 2 (cal AD 860-1050, 55.6\%).

Z-3208 \#266

$1405 \pm 80$

Charcoal from waste pit, Roman period, SU 783, sector VI, Probe 7/3 (cal AD 540-710, 67.4\%).

Z-3209 \#283

$1850 \pm 85$

Charcoal from waste pit, Roman period, SU 764, sector VI, Probe 7/3 (cal AD 700-260, 65.0\%).

Z-3210 \#364

$1750 \pm 60$

Charcoal from grave, Roman period, SU 785, sector VI, Probe 4/4 (cal AD 220-390, 68.2\%). 
Z-3211 \#354

$1100 \pm 80$

Charcoal from burnt trench coat, medieval, SU 1710B, sector XII, quadrant P-19 (cal AD 860-1030, $63.8 \%)$.

Z-3212 \#368

$1210 \pm 80$

Charcoal from pillar, medieval, SU 1737, sector XII, quadrant P-18 (cal AD 690-750, 13.8\%; 760$900,49.4 \%)$.

Z-3213 \#246

$635 \pm 65$

Charcoal from hearth, medieval, SU 1722, sector XII, quadrant O-16 (cal AD 1280-1330, 28.9\%; $1340-1400,39.7 \%)$.

Z-3214 \#338

$1280 \pm 110$

Charcoal from burial trench, La Téne period, SU 1704C, sector XII, quadrant O-16 (cal AD 650$890,68.2 \%)$.

Z-3216 \#371

$1760 \pm 80$

Charcoal from ruins layer, Roman period, SU 2091, sector XV, quadrant K-30 (cal AD 210-390, $59.5 \%)$.

Z-3242 \#388

$99.3 \pm 1.3 \mathrm{pMC}$

Charcoal from pit, depth $0.6 \mathrm{~m}$, SU 2131, sector XV.

Z-3243 \#426

$101.6 \pm 1.2 \mathrm{pMC}$

Charcoal from pit, depth $0.5 \mathrm{~m}$. SU 2180, sector XV, quadrant O-33, 34 .

Z-3244 \#427

$160 \pm 70$

Charcoal from pit, depth $0.5 \mathrm{~m}$. SU 2183, sector XV, quadrant N-33 (cal AD 1660-1700, 11.5\%; $1720-1820,30.2 \%$; 1830-1880, 14.6\%; 1910-1950, 11.9\%).

Z-3246 \#445

$1740 \pm 70$

Charcoal from pit, depth 0.7 m. SU 1672, sector XV, quadrant K-29 (cal AD 230-400, 68.2\%).

Z-3247 \#278

$1410 \pm 110$

Charcoal from Roman layer, depth 2.0 m. SU 1562, sector VII, quadrant A-1 (cal AD 530-730, $60.4 \% ; 740-780,6.6 \%)$.

\section{Z-3248 \#431}

$101.1 \pm 1.5 \mathrm{pMC}$

Charcoal from Roman layer, depth 2.0 m. SU 1574, sector VII, quadrant B-1.

Z-3249 \#433

$1730 \pm 70$

Charcoal from Roman period, depth 1.5 m. SU 805, sector VII, quadrant B-4 (cal AD 230-410, $68.2 \%)$.

Z-3250 \#434

$2370 \pm 140$

Charcoal from Roman period, depth 2.0 m. SU 1575, sector VII, quadrant B-1 (800-350 cal BC, $66.4 \%)$.

Z-3251 \#402

$1380 \pm 70$

Charcoal from the grave, SU 294, sector VI, probe 5/4 (cal AD 590-720, 63.3\%).

Z-3253 \#404

$1290 \pm 55$

Charcoal from ruins layer, SU 767, sector VI, probe 13/1 (cal AD 660-780, 68.2\%).

Z-3257 \#408

$1380 \pm 75$

Charcoal from grave filling, SU 295, sector VI, Probe 4/4 (cal AD 590-720, 60.2\%; 740-770, 8.0\%). 
Z-3258 \#415

$1850 \pm 60$

Charcoal from ruins layer, Roman period, SU 776, sector VI, Probe 13/2 (cal AD 80-110, 7.9\%; $120-250,60.3 \%)$.

Z-3364 \#448

$1320 \pm 80$

Charcoal, SU 1589, sector VII, quadrant A-7 (cal AD 640-810, 68.2\%).

Z-3365 \#449

$1685 \pm 100$

Charcoal, SU 809, sector VII, quadrant A-1 (cal AD 230-440, 59.8\%).

Z-3366 \#459

$1860 \pm 80$

Charcoal, SU 1591, sector VII, quadrant A-10 (cal AD 60-250, 68.2\%).

Z-3367 \#460

$1915 \pm 55$

Charcoal, SU 1582, sector VII, quadrant A-7 (cal AD 20-140, 59.8\%).

Z-3368 \#468

$745 \pm 85$

Charcoal, SU 2343, sector XI, quadrant L-6 (cal AD 1180-1310, 59.7\%; 1350-1390, 8.5\%).

Z-3370 \#476

$705 \pm 85$

Charcoal, SU 2367, sector VII, quadrant N-5 (cal AD 1240-1330, 45.1\%; 1340-1400, 22.4\%).

Z-3371 \#479

$1505 \pm 65$

Charcoal, SU 2368, sector XI, quadrant N-5 (cal AD 460-500, 8.0\%; 530-640, 54.4\%).

Z-3373 \#502

$2070 \pm 70$

Charcoal, SU 3115, sector XI, quadrant K-7 (180 cal BC-cal AD 10, 86.2\%).

Z-3374 \#484

$2200 \pm 100$

Charcoal, SU 2892, sector XV, quadrant M-30 (390-160 cal BC, 65.2\%).

Z-3375 \#232

$3360 \pm 80$

Charcoal, SU 1089, sector VIII, quadrant B-14 (1740-1520 cal BC, 68.2\%).

BOSNIA AND HERZEGOVINA

Z-3384 Fojnica

$2765 \pm 75$

Bone from a cave near Fojnica, Bosnia and Herzegovina, was submitted in 2004 by D Marjanović, Institute for Genetical Engineering and Biotechnology, Sarajevo, Bosnia and Herzegovina (1000$830 \mathrm{cal} \mathrm{BC}, 68.2 \%)$.

\section{Lištani-Podvornice Series}

Charcoal found at the Lištani-Podvornice site near Livno $\left(43^{\circ} 52^{\prime} 32.2^{\prime \prime} \mathrm{N}, 16^{\circ} 46^{\prime} 38.4^{\prime \prime} \mathrm{E}\right)$, with the remains of a late Antique tomb, early Christian churches, and medieval necropolis, was submitted in 2001 and 2004 by M Marić, Franciscan Museum and Gallery Gorica, Livno, Bosnia and Herzegovina.

Z-3097 Quadrant C2 b/d

$1695 \pm 95$

cal AD 230-440, 63.4\%.

Z-3377 Quadrant B6, pit B, Probe 1

$1745 \pm 55$

cal AD 230-390, 68.2\%.

Z-3378 Quadrant C6 c/d, pit E, Probe 1

$180 \mathrm{cal}$ BC-cal AD 10, 66.5\%.

$2080 \pm 70$ 


\section{Mostar Series}

Six wood and 2 charcoal samples taken during the repair of a single-arch stone bridge built in 15571566 by the order of Ottoman Sultan Süleyman the Magnificent over the Neretva River in Mostar, Bosnia and Herzegovina $\left(43^{\circ} 20^{\prime} 6.7^{\prime \prime} \mathrm{N}, 17^{\circ} 48^{\prime} 57.6^{\prime \prime} \mathrm{E}\right)$, were collected and submitted in 2003 by $\breve{Z}$ Peković, Omega Inženjering Ltd., Dubrovnik, and A Milošević, Museum of Croatian Archaeological Monuments, Split. The results point to several periods of construction and repairs of the bridge and the towers at each end, spanning from the 12th to the 18th century (Obelic et al. 2007). Results were confirmed by dendrochronological dating of wood samples with visible tree rings.

Z-3317 Pine beam \#15

$585 \pm 65$ Wooden bridge, left bank. Dendrochronological date: AD 1385 (cal AD 1300-1370, 47.1\%; 1380$1420,21.1 \%)$.

Z-3318 Oak beam \#2

$415 \pm 65$

Wooden bridge, right bank. Dendrochronological date: AD 1485 (cal AD 1420-1530, 54.2\%; 1590$1620,14.0 \%)$.

Z-3319 Pine beam \#3

$395 \pm 65$

Bridge, left bank. Dendrochronological dates: AD 1367, 1388 (cal AD 1430-1530, 45.2\%; 1570$1630,23.0 \%)$.

Z-3320 Oak beam \#4

$220 \pm 60$

Repairs of the stone bridge. Dendrochronological date: AD 1737 (cal AD 1630-1690, 23.2\%; 1720$1810,32.9 \%$; 1920-1960, 9.9\%).

Z-3321 Pine beam \#5

$980 \pm 65$ Suspension bridge, left bank. Dendrochronological dates: AD 1001, 1009, 1050, 1052, 1082 (cal AD 990-1060, 30.0\%; 1070-1160, 38.2\%).

Z-3440 Pine beam \#10

$\mathbf{5 7 5} \pm \mathbf{7 0}$

First level of the Tara tower. Dendrochronological date: AD 1316 (cal AD 1300-1370, 43.6\%; $1380-1420,24.6 \%)$.

Z-3441 Charcoal \#16

$805 \pm 65$

Anchorage of the suspension bridge, left bank (cal AD 1170-1280,68.2\%).

Z-3442 Charred beam \#17

$580 \pm 65$

Basement of Tara tower (cal AD 1300-1370, 45.5\%; 1380-1420, 22.7\%).

\section{MACEDONIA}

\section{Pilavo Series}

Food from the archaeological site of Pilavo in the village of Burlićevo near Kičevo, Macedonia $\left(41^{\circ} 30^{\prime} 52^{\prime \prime} \mathrm{N}, 20^{\circ} 57^{\prime} 48^{\prime \prime} \mathrm{E}\right)$, was submitted 2002 by I Kolištrkoska Nasteva, Museum of Macedonia, Skopje.

Z-3154 Pilavo 1

$5575 \pm 100$

Grain (4540-4330 cal BC, 65.3\%).

Z-3155 Pilavo 2

$2395 \pm 70$

Cattle food, vetch (Vicia sativa) (760-680 cal BC, 18.8\%; 550-390, 49.4\%). 


\section{FRANCE}

\section{Saint Claude Series}

Charcoal and bone samples from the funerary chapel of the Palais Abbatial in Saint Claude-Jura (La Franche Comté), France ( $\left.46^{\circ} 23^{\prime} 16^{\prime \prime} \mathrm{N}, 5^{\circ} 51^{\prime} 50^{\prime \prime} \mathrm{E}\right)$, were collected and submitted in 2003 by S Bully and M Čaušević-Bully, APAHJ (Association de Promotion de l'Archéologie du Haut Jura). Comment (SB): ${ }^{14} \mathrm{C}$ dating confirms the first half of 11 th century (Bully 2008).

Z-3268 Sector IVg, SU 4057

$950 \pm 70$

Animal bones (cal AD 1020-1170, 68.2\%).

Z-3269 Sector IVh, SU 4061

$1035 \pm 70$

Animal bones (cal AD 890-930, 9.8\%; 940-1050, 47.8\%; 1090-1120, 6.3\%).

Z-3270 Sector IVf, SU 4107

$910 \pm 70$

Animal bones (cal AD 1030-1190, 68.2\%).

Z-3271 Sector IVe, SU 4039

$1065 \pm 70$

Charcoal (cal AD 890-1030, 68.2\%).

Z-3272 Sector IVf, SU 4116

$1085 \pm 70$

Charcoal (cal AD 890-1020, 68.2\%).

Z-3273 Sector IVg, SU 4133

$1120 \pm 80$

Charcoal (cal AD 860-1000, 62.1\%).

Z-3274 Sector IVg, TP 4143 / 0.4144

$1005 \pm 65$

Charcoal (cal AD 970-1070, 42.7\%; 1080-1160, 25.5\%).

Z-3298 Sector IIIa, SU 3067, Cav. 328, Se 83

$735 \pm 70$

Human bones from grave (cal AD 1210-1310, 60.1\%; 1360-1390, 8.1\%).

Z-3299 Sector II, SU 2026, Fos. 210, Se 56

$195 \pm 65$

Human bones from grave (cal AD 1640-1700, 17.3\%; 1720-1820, 34.4\%; 1840-1880, 5.3\%; 1910$1950,11.2 \%)$.

Z-3301 Sector Vd, SU 5088, cav. 580, Se 101

$1010 \pm 70$

Human bones from walled grave (cal AD 970-1070, 42.0\%; 1080-1160, 23.7\%).

Z-3302 Sector IIIa-b, SU 3094, Fos. 318, Se 28

$940 \pm 70$

Human bones, grave under stone slabs (cal AD 1020-1170, 68.2\%).

Z-3324 Sector II, SU 2049, Fos. 222, Se 78

$935 \pm 55$

Human bones from grave (cal AD 1020-1160, 68.2\%).

Z-3972 St Lupicin

$1710 \pm 80$

A wooden bottom in the walled tomb, SU 0.115, from the church Our Lady of the Nativity in Saint Lupicin, department Jura, region Franche-Comté, France $\left(46^{\circ} 24^{\prime} \mathrm{N}, 5^{\circ} 47^{\prime} \mathrm{E}\right)$, was collected and submitted by S Bully and M Čaušević-Bully. By removing the pavement of the church built in the 11th century, a privileged burial was found, identified as the tomb of St Lupicin, the second abbot of Jura, who died about AD 480 (Bully and Čaušević-Bully 2008) (cal AD 230-430, 68.2\%). 


\section{ACKNOWLEDGMENTS}

We thank B Mustač and E Hernaus for sample preparation. Work prepared under the Project Grant 098-0982709-2741 from Ministry of Science, Education and Sports of the Republic of Croatia.

\section{REFERENCES}

Baldia M. 2009. The Comparative Archaeology $\mathrm{WEB}^{\circ}$ [online]. URL: http://www.comp-archaeology.org. Accessed 20 January 2011.

Bronk Ramsey C. 2001. Development of the radiocarbon calibration program. Radiocarbon 43(2A):355-63.

Bully S. 2008. Étude de topographie monastique: l'ancien palais abbatial de Saint-Claude (Jura), Ve-XVIII siècle. Bulletin du centre d'études médiévales d'Auxerre 12 [online]. URL: http://cem.revues.org/ index 7622.html. Accessed 20 January 2011.

Bully S, Čaušević-Bully M. 2008. Saint-Lupicin (Jura), église Notre-Dame de la Nativité. Sondage archéologique à la croisée du transept. Bulletin du centre d'études médiévales d'Auxerre 12 [online]. URL: http://cem.revues.org/index6582.html. Accessed 20 January 2011.

Čufar K, Sekelj-Ivančan T. 2008. Dendrokronološko datiranje drva s lokaliteta Torčec-Gradić u sjevernoj $\mathrm{Hr}$ vatskoj [Dendrochronological dating of wood from the site Torčec-Gradić in northern Croatia]. Podravina, Journal for Multidisciplinary Investigations VII(13):30-40.

Forenbaher S, Kaiser T. 2001. Nakovana Cave: an Illyrian ritual site. Antiquity 75:677-8.

Horvatinčić N, Barešić J, Krajcar Bronić I, Obelić B. 2004. Measurement of low ${ }^{14} \mathrm{C}$ activities in a liquid scintillation counter in the Zagreb Radiocarbon Laboratory. Radiocarbon 46(1):105-16.

Ložnjak D. 2002. Naselje bosutske grupe na iločkom Gornjem gradu [The Bosut group settlement in the Upper Town Ilok]. Prilozi Instituta za arheologiju u Zagrebu 19:63-78.

Marijanović B. 2003. Crno vrilo-novi grob starijeg neolitika u Dalmaciji. Opuscula Archaeologica 27:37-41.

Marković Z. 2003. O genezi i počecima licenskokeramičke kulture u sjevernoj Hrvatskoj [On genesis and appearance of the Litzen-pottery culture in Northern Croatia]. Opuscula Archaeologica 27:117-50.

Mook WG, van der Plicht J. 1999. Reporting ${ }^{14} \mathrm{C}$ activities and concentrations. Radiocarbon 41(3):227-39.

Ničetić A. 2003. Grafike koje ipak ne prikazuju Dubrovnik 15. i 16. stoljeća. Anali Dubrovnik 41:75-89.

Obelić B. 1989. The radiocarbon data base at Rudjer Bošković Institute Radiocarbon Laboratory. Radiocarbon 31(3):1057-62.

Obelić B. 2009. Rezultati ${ }^{14} \mathrm{C}$ analiz vzorcev oglja [Results of ${ }^{14} \mathrm{C}$ analyses of charcoal samples] in Pod Kotom - jug pri Krogu I/II. In: Šavel I, editor. Zbirka: Arheologija na avtocestah Slovenije [Collection: Archaeology on Slovenian Highways], MP 03, Coget-
inci-Beltinci. Ljubljana: Zavod za varstvo kulturne dediščine Slovenije. p 146-7.

Obelić B, Horvatinčić N, Srdoč D, Krajcar Bronić I, Sliepčević A, Grgić S. 1994. Rudjer Bošković Institute radiocarbon measurements XIII. Radiocarbon 36(2):303-24.

Obelić B, Horvatinčić N, Krajcar Bronić I. 2002. Rudjer Bošković Institute radiocarbon measurements XV. Radiocarbon 44(2):601-30.

Obelić B, Krznarić Škrivanko M, Marijan B, Krajcar Bronić I. 2004. Radiocarbon dating of Sopot culture sites (Late Neolithic) in eastern Croatia. Radiocarbon 46(1):245-58.

Obelić B, Krajcar Bronić I, Barešić J, Peković Ž, Milošević A. 2007. Dating of the old bridge in Mostar, Bosnia and Herzegovina. Radiocarbon 49(2):617-23.

Portner A, Obelić B, Krajcar Bronić I. 2010. ZAGRADA - the new Zagreb Radiocarbon Database. Radiocarbon 52(3):941-7.

Radić Rossi I. 2004. I resti riemersi del Porto medioevale di Dubrovnik. In: De Maria L, Turchetti R, editors. Rotte e porti del Mediterraneo dopo la caduta dell'Impero romano d'occidente. IV Seminario, Genoa, 1819 June 2004. p 171-88.

Radić Rossi I. 2008. Arheološka baština u podmorju Kaštelanskog zaljeva [The underwater archaeological heritage in Kaštela Bay]. Archaeologia Adriatica 11: 489-506.

Sankovič S. 2009. Zgodnjebronastodobne najdbe [Early Bronze Age findings] in Pod Kotom - jug pri Krogu I/ II. In: Šavel I, editor. Zbirka: Arheologija na avtocestah Slovenije [Collection: Archaeology on Slovenian Highways], MP 03, Cogetinci-Beltinci. Ljubljana: Zavod za varstvo kulturne dediščine Slovenije. p 139-47.

Sekel-Ivančan T. 2004. Torčec, Ledine 2004 - ranosrednjevjekovno naselje [Torčec, Ledine 2004-Early Middle Ages settlement]. Annales Instituti Archaeologici I(1):4-49.

Sekelj-Ivančan T. 2005. Probna arheološka istraživanja na položaju Blaževo Pole 6 u Torčecu kraj Koprivnice [Trial excavations at the Blaževo Pole site in Torečc near Koprivnica]. Annales Instituti Archaeologici I(1):40-4.

Sekelj-Ivančan T, Tkalčec T. 2004. Arheološko nalazište Torčec-Gradić [Archaeological site Torčec-Gradić]. Podravina, Journal for Multidisciplinary Investigations III(6):71-106.

Skelac G. 1997. Prapovijesno nalazište Slavča [The prehistoric site of Slavča]. Opuscula Archaeologica 21: 217-33. 
Srdoč D, Breyer B, Sliepčević A. 1971. Rudjer Bošković Institute radiocarbon measurements I. Radiocarbon 13(1):135-40.

Srdoč D, Obelić B, Horvatinčić N, Sliepčević A. 1979. Measurement of the ${ }^{14} \mathrm{C}$ activity of the ANU sucrose secondary standard by means of the proportional counter technique. Radiocarbon 21(3):321-8.

Srdoč D, Obelić B, Horvatinčić N, Krajcar Bronić I, Sliepčević A. 1984. Rudjer Bošković Institute radiocarbon measurements VIII. Radiocarbon 26(3):44960.

Srdoč D, Obelić B, Sliepčević A, Krajcar Bronić I, Horvatinčić N. 1987. Rudjer Bošković Institute radiocarbon measurements X. Radiocarbon 29(1):135-47.

Srdoč D, Obelić B, Horvatinčić N, Krajcar Bronić I, Sliepčević A. 1989. Rudjer Bošković Institute radiocarbon measurements XI. Radiocarbon 31(1):85-98.

Srdoč D, Horvatinčić N, Krajcar Bronić I, Obelić B,
Sliepčević A. 1992. Rudjer Bošković Institute radiocarbon measurements XII. Radiocarbon 34(3):15575.

Stuiver M, Polach HA. 1977. Discussion: reporting of ${ }^{14} \mathrm{C}$ data. Radiocarbon 19(3):355-63.

Tkalčec T. 2005. Gudovac-Gradina 2004. Annales Instituti Archaeologici I(1):50-5.

Tomičić Ž, Tkalčec T, Dizdar M, Ložnjak D. 2001. Veliki Gradiš, Veliko Gradišće-plemićki grad Vrbovec kraj Huma na Sutli (Stanje istraživanja 2001. godine) [Veliki Gradiš, Veliko Gradišće-feudal town Vrbovec near Hum na Sutli (as of 2001)]. Prilozi Instituta za arheologiju и Zagrebu 19:253-74.

Uglešić A. 2005. Podvršje, Glavčine, ranokršćansko razdoblje, dvojne crkve, geminate [Podvršje, Glavčine, Early Christian period, Twin Churches, geminate]. Hrvatski arheološki godišnjak 2:301-4. 